\title{
Coexistence of endothelial dysfunction, fibrinolysis activation and diminished interleukin 6 level in morbid obesity
}

\author{
Wspótistnienie uszkodzenia śródbłonka naczyniowego, aktywacji fibrynolizy i obniżonego \\ poziomu interleukiny 6 w otyłości ogromnej
}

\author{
Iza Iwan-Ziętek¹, Katarzyna Szot², Małgorzata Michalska², Przemysław Adamczyk³, Jacek Chojnowski³, \\ Krzysztof Góralczyk², Barbara Ruszkowska-Ciastek², Grażyna Bednarek², Tadeusz Sulikowski", \\ Zbigniew Ziętek ${ }^{\circledR}$, Danuta Rość ${ }^{2}$
}

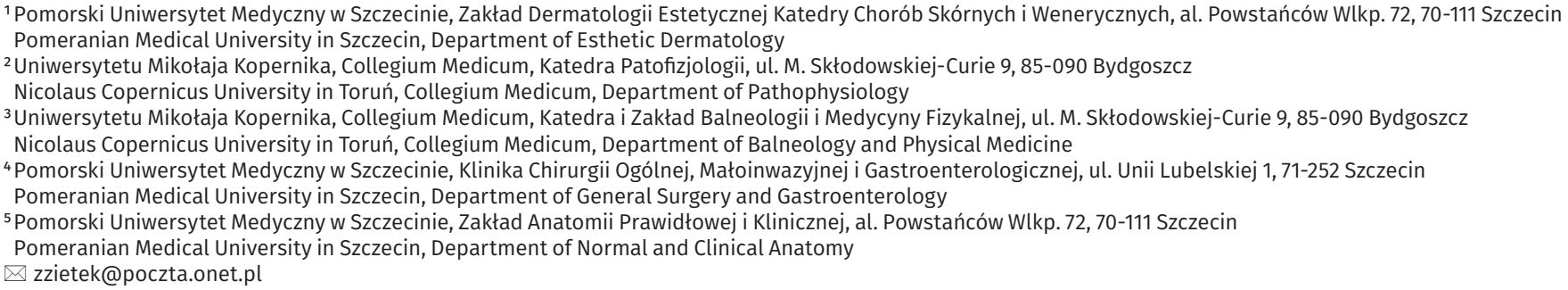

\section{ABSTRACT}

Introduction: The aim of the study was to assess selected parameters of endothelial dysfunction and haemostasis in morbidly obese patients. So far, reports related to the disorders within the cells of the endothelium in morbid obesity are surprisingly sparse. Materials and methods: The study was conducted in 74 morbidly obese patients with body mass index (BMI) $>40 \mathrm{~kg} / \mathrm{m}^{2}$ and in 30 healthy volunteers with normal BMI. The following tests were performed on the citrated plasma of venous blood: soluble Thrombomodulin concentrations (sTM), von Willebrand factor (vWF:Ag), tissue plasminogen activator antigen (t-PA:Ag), plasminogen activator inhibitor type 1 antigen (PAI-1:Ag) concentrations, and soluble fraction of selectin $\mathrm{E}$ and $\mathrm{P}$ (sE-selectin and sP-selectin) and interleukin 6 (Il-6) concentrations.
Results: The findings of the study indicate that there were markedly higher concentrations of sTM, tPA:Ag, PAI-1:Ag, sE-selectin and reduced concentrations of VWF:Ag and sP-selectin in the plasma of the patients with morbid obesity. The mean concentration of Il-6 was also significantly lower in morbid obesity. Conclusions: Morbid obesity coexists with endothelial injury, which increases the risk of possible thromboembolic complications. Increased fibrinolytic system components and inhibition of platelet activation can be treated as compensatory mechanisms that reduce the risk of these complications. A decrease in Il-6 may be an indicator of inhibited inflammation, but it may also lead to increased susceptibility to infectious diseases.

Keywords: morbid obesity; haemostasis; platelet; thromboembolic complications; inflammation.

\begin{abstract}
ABSTRAKT
Wstęp: Celem pracy była ocena wybranych parametrów dysfunkcji śródbłonka i hemostazy u chorych z otyłością. Badania dotyczące zaburzeń komórek śródbłonka w otyłości ogromnej są w literaturze spotykane zaskakująco rzadko.

Materiały i metody: Badanie przeprowadzono u 74 chorych z otyłością ze wskaźnikiem masy ciała (BMI) $>40 \mathrm{~kg} / \mathrm{m}^{2}$ oraz u 30 zdrowych ochotników z prawidłowym BMI. W osoczu krwi chorych przeprowadzono testy stężenia: rozpuszczalnej formy trombomoduliny (sTM), antygenu czynnika von Willebranda (vWF:Ag), antygenu tkankowego aktywatora plazminogenu (t-PA:Ag) i antygenu inhibitora aktywatora plazminogenu typu 1 (PAI-1:Ag) oraz rozpuszczalnej frakcji selektyny E i P (sE-selektyny i sP-selektyny). Dokonano także pomiaru stężenia interleukiny 6 (Il-6).
\end{abstract}

Wyniki: Wyniki badań wskazały znaczne zwiększenie stężenia sTM, t-PA:Ag, PAI-1:Ag i sE-selektyny oraz istotne zmniejszone stężenie vWF:Ag i sP-selektyny w otyłości ogromnej w porównaniu z grupą kontrolną. Wykazano także w otyłości ogromnej obniżenie stężenia Il-6.

Wnioski: W otyłości ogromnej dochodzi do uszkodzenia śródbłonka, co zwiększa ryzyko ewentualnych powikłań zakrzepowo-zatorowych. Zwiększenie składowych układu fibrynolizy oraz hamowanie aktywacji płytek można traktować jako mechanizmy kompensacyjne zmniejszające ryzyko powikłań. Spadek stężenia Il-6 może być wyrazem ograniczania procesu zapalnego, ale równocześnie może to być przyczyna zwiększonej podatności na choroby infekcyjne.

Słowa kluczowe: otyłość patologiczna; hemostaza; płytki krwi; powikłania zatorowo-zakrzepowe; zapalenie. 


\section{INTRODUCTION}

According to the World Health Organization, globally 1.9 billion people are overweight and more than 600 million patients suffer from obesity. In the past 35 years the number of people with excess body weight, i.e. body mass index (BMI) $>25 \mathrm{~kg} / \mathrm{m}^{2}$ has doubled [1]. According to GUS and EUROSTAT data, half of Poles are reported to be affected by overweight and obesity, and obesity III $^{\circ}$. In other words morbid obesity (BMI of $40 \mathrm{~kg} / \mathrm{m}^{2}$ or above, or from about $120 \mathrm{~kg}$ ) affects as many as 1.5 million people.

Body weight is strictly controlled by complex homeostatic mechanisms. Obesity is a condition in which energy intake chronically exceeds energy expenditure. The rising prevalence of obesity results from contemporary environmental and lifestyle factors such as increased access to palatable foods and reduced requirements for physical exercise in comparison to ancient hunter-gatherer lifestyles that were characterized by unpredictable periods of starvation [2]. Epidemiological data indicate that increased BMI is associated with the risk of death. Mortality from heart disease and thromboembolic incidents occur more commonly in people with obesity. Other health conditions such as insulin resistance and diabetes cause associated medical complications in obese patients $[3,4,5,6]$.

The endothelium, which is considered a dynamic endocrine organ indispensable for the maintenance of vascular haemostasis, is a crucial element that links obesity with other metabolic disorders. Mechanical damage or loss of endothelial integrity elicits endothelial activation and brings about pathological disorders such as hypertension, atherosclerotic lesion or thrombus formation [3]. Vascular dysfunction is associated with insufficient or excessive production of specific markers of endothelial damage, such as von Willebrand factor (vWF) or soluble thrombomodulin (STM) [6, 7, 8], and other parameters of fibrinolysis, such as tissue plasminogen activator (t-PA) and plasminogen activator of inhibitor type 1 antigen (PAI-1:Ag) [4, 9, 10, 11].

The current research evaluating the role of the individual components of the blood vessels show the vital role of adipose tissue [4]. Adipose tissue is no longer considered as a passive energy storage, but as one of the most important components that are involved in the control of vascular tone, as well as in inflammatory reactions associated with obesity [9].

According to many authors, obesity is considered to be systemic chronic inflammation $[4,12,13,14,15]$. On the other hand, there is a hypothesis suggesting that chronic inflammation in obese people occurs to protect the human body against excessive accumulation of fat to prevent a human reaching a weight and size that does not allow them to move and walk, and generally reduces physical efficiency $[12,14,16]$.

The inflammatory mediators causing the exposure of adhesion proteins from the selectin family, and elevated blood levels of the soluble fraction of P-selectin (sP-selectin), and E (sE-selectin) are an expression of activation and damage to endothelial cells $[17,18,19]$.
Understanding the mechanisms that depend on factors secreted by processes in a number of endothelial cells is currently the subject of many investigations, but the literature shows only a few reports related to disorders within the cells of the endothelium in morbid obesity. Therefore, the aim of the present study was to assess the chosen parameters of endothelial dysfunction and haemostasis in patients with a BMI greater than $40 \mathrm{~kg} / \mathrm{m}^{2}$, qualified for balneological treatment or surgical treatment of obesity.

\section{MATERIALS AND METHODS}

The study was conducted in 104 individuals, including 74 morbidly obese patients (BMI $>40 \mathrm{~kg} / \mathrm{m}^{2}$ ) and 30 healthy volunteers with normal BMI (under $24 \mathrm{~kg} / \mathrm{m}^{2}$ ) enrolled to the control group. The patients were under the care of the Clinic of Balneology and Physical Medicine in Ciechocinek, Poland, and 38 patients were qualified for elective gastric bypass surgery. Blood was obtained from the patients prior to treatment.

Venous blood from patients and volunteers was collected in the morning hours in a fasting state in order to obtain plateletpoor plasma, and the blood samples were centrifuged. Blood was then divided into sections and stored at minus $86^{\circ} \mathrm{C}$ until an assay was performed, but not longer than 6 months. The following tests were performed on the citrated plasma of venous blood:

1. The concentration of sTM by test: TM-IMUBIND Thrombomodulin ELISA, American Diagnostica, ref.: male 4.00-5.35 ng/mL, female $2.73-4.79 \mathrm{ng} / \mathrm{mL}$.

2. The concentration of soluble fraction of E Selectin (sE-selectin) by the immunosorbent method (ELISA) using Bender Medsystem mono- and polyclonal antibodies market enzymatically, ref.: $23-79.2 \mathrm{ng} / \mathrm{mL}$.

3. Antigen of tissue plasminogen activator concentration using American Diagnostica test IMUBIND Tissue t-PA ELISA kit, ref.: 2-12 ng/mL.

4. Antigen of plasminogen activator inhibitor type 1, using American Diagnostica test IMUBIND Tissue PAI-1:Ag ELISA kit, ref.: $2-47 \mathrm{ng} / \mathrm{mL}$.

5. The concentration of vWF using an ASSERACHROM vWF:Ag test, ref.: 50-160\%.

6. The concentration of soluble fraction of P Selectin (sP-selectin) by the immunosorbent method (ELISA) using Bender Medsystem mono- and polyclonal antibodies market enzymatically, ref.: 92-212 ng/mL.

7. The concentration of interleukin 6 (Il-6) was assessed by the immunosorbent method (ELISA) using the eBioscience test, ref.: $<6.6 \mathrm{pg} / \mathrm{mL}$.

The study was approved by the Bioethics Committee of Collegium Medicum in Bydgoszcz, Nicolaus Copernicus University in Toruń. Written informed consent was received from each participant before the study. Statistical analysis was performed using Statistica 12 software (StatSoft ${ }^{\circledR}$ ). P-value of $<0.05$ was considered significant. The Shapiro-Wilk test was used to assess the normality of distributions, with the use of 
Student's t-test; the mean and standard deviation (SD) were determined for each variable. Parameters with values deviating from normal distribution were described by the median (Me), lover quartile (Q1), and upper quartile (Q3).

\section{RESULTS}

Figure 1 presents the concentration of markers of endothelial dysfunction (sE-selectin and STM) in the blood of patients with morbid obesity in comparison to the control group. Both studied parameters were significantly elevated in the blood of obese patients compared to healthy volunteers $(\mathrm{p}<0.001$; $\mathrm{p}<0.05)$.
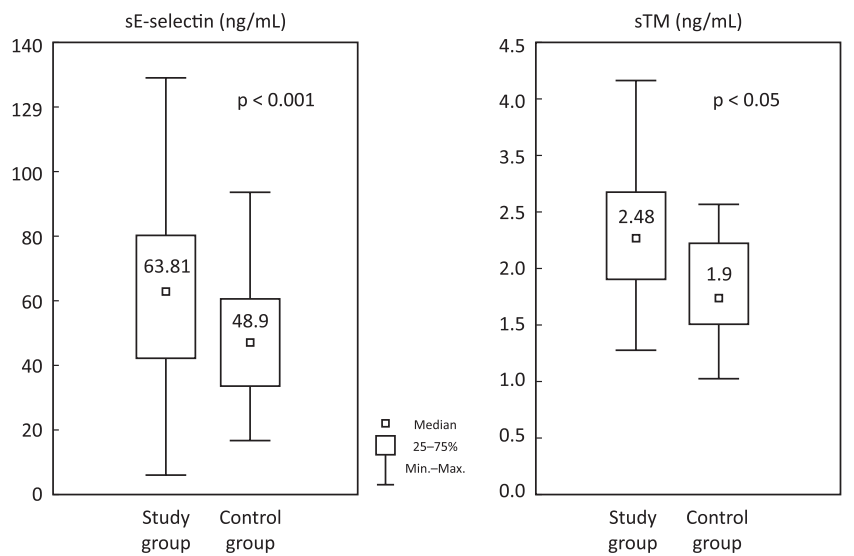

FIGURE 1. Markers of endothelial dysfunction in patients with morbid obesity and healthy controls

Figure 2 shows the concentration of factors present in the blood and associated with the activity of platelets in the process of haemostasis - the concentration of VWF:Ag and sP-selectin. In the blood of obese patients significantly lower concentrations of vWF:Ag $(p<0.005)$ and sP-selectin $(p<0.009)$ than in the control group were found.
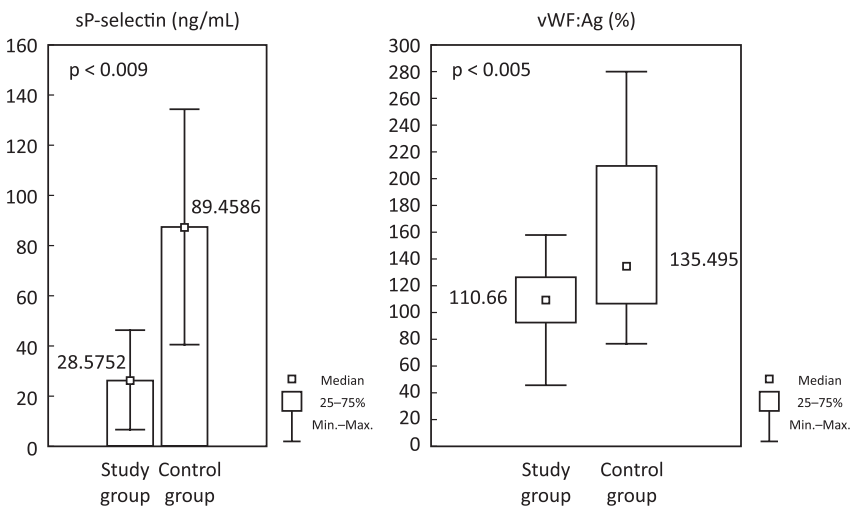

FIGURE 2. Factors of platelets haemostasis in patients with morbid obesity and healthy controls

Figure 3 presents the concentration of tissue plasminogen activator antigen t-PA:Ag and PAI-1:Ag, the factors of intravascular fibrinolysis in the blood of patients with morbid obesity compared to the control group. The mean concentrations of studied factors were significantly higher in patients compared to the control group $(\mathrm{p}<0.02 ; \mathrm{p}<0.001)$.

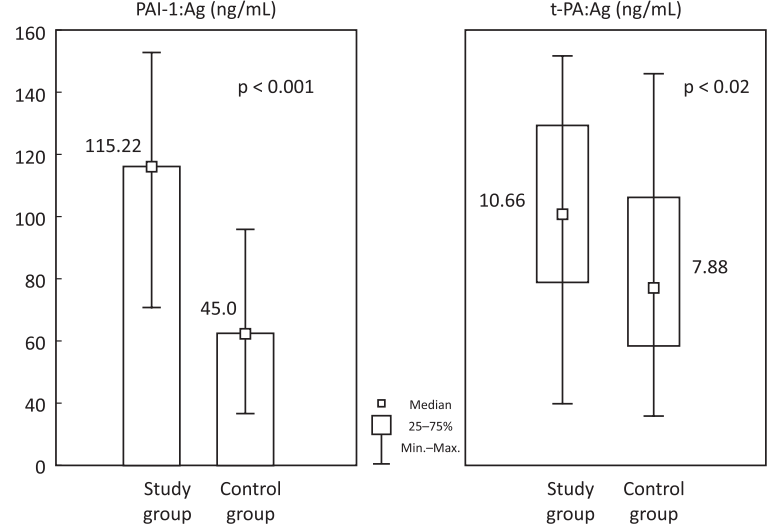

FIGURE 3. The mean concentrations of tissue plasminogen activator antigen (t-PA:Ag) and plasminogen activator inhibitor type 1 antigen (PAl-1:Ag) in patients with morbid obesity and healthy controls

The results obtained from the analysis of Il-6 levels in blood are shown in figure 4. Interleukin-6 is the main cytokine associated with the inflammatory process. In the blood of obese patients Il-6 concentration was significantly lower than in healthy subjects $(\mathrm{p}<0.009)$.

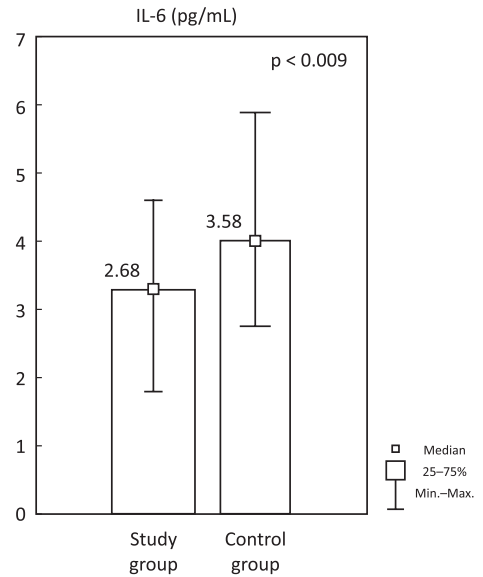

FIGURE 4. The concentration of interleukin-6 (II-6) in patients with morbid obesity and healthy controls

\section{DISCUSSION}

The study demonstrated that in comparison with the control group, in the blood of patients with morbid obesity sTM, t-PA:Ag, sE-selectin and PAI-1:Ag showed higher levels and simultaneous lower concentrations of vWF:Ag, sP-selectin and Il-6.

One of the many functions of a healthy vascular endothelium is to avoid unwanted intraluminal blood clotting and the formation of a potentially lethal thrombus. Thrombomodulin (TM), which is an essential anticoagulant, is an integral membrane glycoprotein expressed on the lumenal surface of vascular endothelial cells that constitute a receptor for thrombin and modulate the substrate specificity of thrombin. Complex formation between thrombin and thrombomodulin prevents thrombin from being able to clot fibrinogen or to activate platelets. Simultaneously, TM-mediated binding of thrombin leading 
to protein $\mathrm{C}$ activation has beneficial anticoagulant outcomes for the vessel wall. Metabolic factors associated with obesity stimulate proteolytic activity that can cause detachment of the thrombomodulin of endothelial cells and increase the STM in plasma. The increase of soluble forms has been observed in certain disease conditions, such as cardiovascular disease with atherosclerosis, diabetes mellitus and pulmonary disease. The plasma level of thrombomodulin has been used as a marker for endothelial injury. Moreover, sTM compared with other markers like vWF or PAI-1 has an advantage over them as the latter are considered as markers of endothelial dysfunctions without indication of its damage. What is more, sTM is not included in acute-phase protein and increased concentration is not observed in inflammatory conditions and infections [7]. The results obtained from the sTM concentrations assessment in plasma in patients with morbid obesity indicate higher levels of this endothelial damage marker in comparison with the control group. These observations correspond with the results reported by many other researchers $[6,8,20]$, who noticed significantly higher sTM levels in obese people. Perivascular adipose tissue, with its enormous extent in obesity, production of adipokines and mechanical vascular influence, contributes to endothelial damage by tearing the integrity of cells and may manifest in the emergence of sTM in blood.

Another marker related to the endothelium has the form of E-selectin, expressed exclusively by endothelial cells, and absent in inactive cells but rapidly induced by inflammatory cytokines [21]. Selectin E facilitate leukocyte rolling, adhesion, and transmigration into the subendothelial space. The emergence of markers of endothelial dysfunction in obesity is linked with the activation of the NF- $\mathrm{B}$ pathway. Adipokines activate transcription of some adhesion molecules like E-selectin [22]. In the present study, plasma concentrations of soluble E-selectin were significantly higher in obese patients. The obtained results indicate endothelial activations related to inflammation on its surface. Other authors reported similar results, i.e. higher levels sE-selectin related to obesity and comorbidities [23, 24], but only a few studies have been concerned with morbid obesity. Hanusch-Enserer et al. and Szafkowski et al. indicated a positive correlation between concentration of sE-selectin and BMI in morbidly obese patients. The conclusions came from the observation of lowering levels of E-selectin related with reduction in body weight $[25,26]$.

Endothelial cells are the principal site of the synthesis and release of tissue-type plasminogen activator, the main enzyme in initiating an endogenous fibrinolytic response, due to its ability to preferentially activate plasminogen on the surface of the developing thrombus. A small fraction of the amount of the circulating antigen t-PA:Ag is active, resulting in a low correlation between the activity of t-PA and the level of an antigen. High concentrations of t-PA:Ag (usually associated with a low activity value of t-PA) and PAI-1:Ag occur in patients with low plasma fibrinolytic potential. A review of the literature indicates that similarly to the present study, patients with morbid obesity have high levels of t-PA:Ag in comparison with the concentration of labelled antigen in the blood in the case of normal weight $[10,20,27]$. The elevated concentration of t-PA:Ag is considered to indicate stimulation the vascular endothelium in patients with morbid obesity.

Numerous recent studies have revealed the disturbance of fibrinolysis in obesity. The production of plasminogen activator inhibitor PAI-1 by adipose tissue has also been recently accentuated. Positive correlations between BMI and PAI-1:Ag levels were found [11]. Elevated PAI-1 also correlated with inflammation, which is initiated by proinflammatory cytokines from adipose tissue. Sources of PAI-1 plasma levels under normal conditions are endothelial cells, platelets and hepatocytes. However, in obesity the PAI-1 biosynthetic capacity of adipose tissue may exceed that of other tissues [28]. The study conducted in patients with BMI above $40 \mathrm{~kg} / \mathrm{m}^{2}$ has shown an extremely high concentration of PAI-1:Ag, almost three times higher than in healthy controls. High plasma levels of PAI-1:Ag are related with increased secretion of PAI-1 as a response to high concentrations of t-PA:Ag (compensation mechanism in the fibrinolysis process). The results of the other parameters evaluated in this study, such as lower concentrations of vWF and P-selectin, suggest that the plates cannot be a major source of PAI-1. The production of PAI-1 by adipose tissue in morbid obesity has been demonstrated.

Von Willebrand factor is a large multimeric glycoprotein present in blood plasma and produced constitutively as ultralarge $\mathrm{VWF}$ in the endothelium (in the Weibel-Palade bodies), megakaryocytes ( $\alpha$-granules of platelets), and subendothelial connective tissue. Von Willebrand factor plays a double role in haemostasis, promotes the adhesion of platelets to the vessel wall in conditions of high blood flow, and also binds plasma coagulation factor VIII to protect it against proteolysis. Many researchers indicate elevated plasma vWF levels in conjunction with an increase in body weight, metabolic syndrome, diabetes, insulin resistance and as an indicator of endothelial damage $[20,29,30,31]$. The present study showed a significantly lower vWF:Ag concentration in the plasma blood of morbidly obese patients than in the blood plasma of healthy people. It is widely known that vWF is involved in the adhesion of platelets in vessels with "shear rates" blood capillaries. It was shown that vWF in plasma comes from endothelial cells and blood platelets. The platelets can contribute about $15 \%$ of total level of vWF. [32]. The results may indicate a reduced rate of platelet activation in morbid obesity and endothelial damage is not excluded. P-selectin links these processes. P-selectin is an adhesion molecule, located similarly to vWF in the platelet $\alpha$ granule and Weibel-Palade body of endothelial cells. Soluble P-selectin is present in the blood. An increased level of sP-selectin is the major predictive factor of cardiovascular events related to platelet turnover and its activation and functions $[18,19]$. The present research observed lower concentrations of sP-selectin in the study group. The plasmatic lower level of sP-selectin may indicate a reduction in platelet activation as well as reduced accumulation of neutrophils at the surface of the vascular endothelium.

According to many authors, obesity is considered to be systemic, chronic inflammation on the surface of the vascular 
endothelium $[13,14]$. However, it appears that inflammation in obesity is a homeostatic mechanism protecting the human body against excessive accumulation of fat. Chronic inflammation in obese people occurs to protect subjects against reaching a weight and size that would prevent them from moving and walking, and reducing normal physical efficiency. Accumulation of body fat is in fact associated with the activation of anabolic processes (including related with insulin), and inflammation causes catabolism, including lipolysis in adipocytes. Inflammation increases energy expenditure and acts to prevent obesity $[12,14,16]$.

Production of Il-6, as well as systemic concentrations, is positively correlated with BMI. The pro-inflammatory role of Il-6 is based on the increase of the production of acute phase proteins [4]. The results obtained in the present study show a reduced concentration of Il- 6 in patients with morbid obesity compared with the concentration of the cytokine in the control group. The results of several studies show a positive correlation between Il- 6 levels in the blood and obesity, which supports the hypothesis of the existence of a homeostatic mechanism as chronic inflammation. A review of the literature shows that there have been a few studies analyzing the role of inflammation in morbid obesity. Morbidly obese patients do not pass into the stable phase of obesity, but a further increase of the size of the fat tissue has been observed. BMI reaches values in excess of $40 \mathrm{~kg} / \mathrm{m}^{2}$, indicating a different pathological mechanism found in morbid obesity, and simultaneously confirms the lack of mechanisms limiting further weight gain, involving inflammatory processes [33].

The hypothesis of the limited presence of inflammation in patients with morbid obesity needs confirmation in further studies.

One of the more significant findings emerging from this study is that elevated levels of STM, t-PA:Ag and sE-selectin suggest endothelial activation and endothelial damage in patients with morbid obesity. It was also shown that high concentrations of t-PA:Ag and PAI-1:Ag designate activation of fibrinolysis on the surface of the vascular endothelium. Decreased vWF:Ag and sP-selectin may indicate reduced stimulation of platelets in patients with morbid obesity and inhibition the function of platelets. This phenomenon can, therefore, be associated with a reduced risk microclots and a reduced involvement of inflammatory mediators stored in granules of platelets. The reduced concentration of Il- 6 may be symptomatic of the reduced role of the inflammatory process in homeostasis of energy in patients with morbid obesity. This research has thrown up many questions in need of further investigation.

\section{CONCLUSIONS}

1. In obese patients, an elevated sTM level may be an indication of damage to the vascular endothelium, e.g. by inflammation, which may be confirmed by elevated sE-selectin levels. These changes demonstrate increased prothrombinic readiness and a significantly higher risk of thromboembolic complications.
2. Elevated levels of t-PA:Ag and PAI-1:Ag components of fibrinolytic system may be implicated in systemic haemostasis, which should also be treated as a compensatory response to neutralizing increased prothrombotic readiness.

3. Reduced concentrations of vWF:Ag and sP-selectin may indicate a compensatory inhibition of platelet activation, which is significantly associated with a reduced risk of microfibrils formation.

4. Reduced concentrations of Il-6 may indicate an attempt to reduce inflammation in patients with massive obesity, but it can also be a sign of a decrease in both innate and acquired immunity, and therefore increased susceptibility to infectious diseases in patients with severe obesity.

\section{REFERENCES}

1. Branca F, Nikogosian H, Lobstein T, editors. The challenge of obesity in the WHO European Region and the strategies for response. Summary. World Health Organization. Europe. Copenhagen: WHO Regional Office for Europe; 2007.

2. Suzuki K, Jayasena CN, Bloom SR. Obesity and appetite control. Exp Diabetes Res 2012. doi: 10.1155/2012/824305.

3. Lobato NS, Filgueira FP, Akamine EH, Tostes RC, Carvalho MHC, Fortes ZB. Mechanisms of endothelial dysfunction in obesity-associated hypertension. Braz J Med Biol Res 2012;45(5):392-400.

4. Frühbeck G, Gómez-Ambrosi J, Muruzábal FJ, Burrell MA. The adipocyte: a model for integration of endocrine and metabolic signaling in energy metabolism regulation. Am J Physiol Endocrinol Metab 2001;280(6):82747. doi: 10.1152/ajpendo.2001.280.6.E827.

5. Wei Y, Liu GL, Yang JY, Zheng RX, Jiang LH, Li YP, et al. Association between metabolic syndrome and vascular endothelium dysfunction in children and adolescents. Genet Mol Res 2014;13(4):8671-8. doi: 10.4238/2014. October.27.7.

6. Swiatkowska-Stodulska R, Skibowska-Bielińska A, Bakowska A, Wiśniewski P, Sworczak K. Assessment of selected haemostatic parameters in obese patients. Endokrynol Pol 2007;58:505-9.

7. Martin FA, Murphy RP, Cummins PM. Thrombomodulin and the vascular endothelium: insights into functional, regulatory, and therapeutic aspects. Am J Physiol Heart Circ Physiol 2013;304(12):1585-97. doi: 10.1152/ajpheart.00096.2013.

8. Urban M, Wojtkielewicz K, Głowińska B, Peczyńska J. Soluble thrombomodulin-a molecular marker of endothelial cell injury in children and adolescents with obesity. Endokrynol Diabetol 2005;11:73-7.

9. Malinowski M, Deja M, Gołba K, Januszewicz P, Roleder T, Woś S. The influence of perivascular adipose tissue on the vascular tone and function. Kardiol Pol 2008;10:317-29.

10. Adamczyk P, Szafkowski R, Rość D, Ponikowska I, Chojnowski J, Firszt-Adamczyk A. Tissue plasminogen activator (t-PA) and plasminogen activator inhibitor type-1 (PAI-1) in morbid obesity. Med Biol Sci 2007;21: 31-6.

11. Michalska M, Iwan-Ziętek I, Gniłka W, Dąbrowiecki S, Góralczyk B, Góralczyk K, et al. PAI- 1 and $\alpha 2$-AP in patients with morbid obesity. Adv Clin Exp Med 2013;22(6):801-7.

12. Ye J, McGuinness OP. Inflammation during obesity is not all bad: evidence from animal and human studies. Am J Physiol Endocrinol Metab 2013;304(5):466-77. doi: 10.1152/ajpendo.00266.2012.

13. Basili S, Pacini G, Guagnano MT, Manigrasso MR, Santilli F, Pettinella C, et al. Insulin resistance as a determinant of platelet activation in obese women. J Am Coll Cardiol 2006;48(12):2531-8.

14. Olszanecka-Glinianowicz M, Zahorska-Markiewicz B. Obesity as inflammatory disease. Postepy Hig Med Dośw 2008;62:249-257.

15. de Heredia FP, Gómez-Martınez S, Marcos A. Obesity, inflammation and the immune system. Proc Nutr Soc 2012;71(3): 332-8.

16. Cottam DR, Mattar SG, Barinas-Mitchell E, Eid G, Kuller L, Kelley DE, et al. The chronic inflammatory hypothesis for the morbidity associated 
with morbid obesity: implications and effects of weight loss. Obes Surg 2004;14:589-600. doi: 10.1381/096089204323093345.

17. Rość D, Ogorzeja W, Kotschy M, Missima M, Jurkowski P. Selectins E and P in the plasma of patients suffering from ischaemic heart disease undergoing surgery with cardiopulmonary bypass. Folia Cardiol 2004;11(10): 733-9.

18. de Faria AP, Ritter AM, Sabbatini AR, Corrêa NB, Brunelli V, Modolo R, et al. Deregulation of soluble adhesion molecules in resistant hypertension and its role in cardiovascular remodeling. Circ J 2016;80(5):1196-201. doi: 10.1253/circj.CJ-16-0058.

19. Polek A, Sobiczewski W, Matowicka-Karna J. P-selectin and its role in some diseases. Postepy Hig Med Dośw 2009;63:465-70.

20. Rość D, Drewniak W, Kinasz-Różycka I, Kulwas A, Michalski A. Thrombomodulin, von Willebrand factor and tissue plasminogen activator in the blood plasma of obese women and men. Pol Merkur Lekarski 2003;15:51820.

21. Żerdziński M, Rychlik M, Partyka R. The selectins role in the development of inflammatory response. Diagn Lab 2012;48:347-51.

22. Shoelson SE, Lee J, Goldfine AB. Inflammation and insulin resistance. J Clin Invest 2006;116(7):1793-801. doi: 10.1172/JCI29069.

23. Matsumoto K, Sera Y, Abe Y, Tominaga T, Horikami K, Hirao K, et al. High serum concentrations of soluble E-selectin correlate with obesity but not fat distribution in patients with type 2 diabetes mellitus. Metabolism 2002;51(7):932-4.

24. Adamska A, Karczewska-Kupczewska M, Nikołajuk A, Otziomek E, Górska M, Kowalska I, et al. Relationships of serum soluble E-selectin concentration with insulin sensitivity and metabolic flexibility in lean and obese women. Endocrine 2014;45(3):422-9. doi: 10.1007/s12020-013-0025-9.

25. Hanusch-Enserer U, Zorn G, Wojta J, Kopp CW, Prager R, Koenig W, et al. Non-conventional markers of atherosclerosis before and after gastric banding surgery. Eur J Heart 2009;30(12):1516-24. doi: 10.1093/eurheartj/ehp108.

26. Szafkowski R, Chojnowski J, Adamczyk P, Rość D, Ponikowska I. Influence of body mass reduction obtained in health resort conditions on endothelium function markers in patients with high level of obesity. Acta Balneol 2012;4(130):220-5.

27. van Guilder GP, Hoetzer GL, Smith DT, Irmiger HM, Greiner JJ, Stauffer BL, et al. Endothelial t-PA release is impaired in overweight and obese adults but can be improved with regular aerobic exercise. Am J Physiol Endocrinol Metab 2005;289(5):807-13. doi: 10.1152/ajpendo.00072.2005.

28. Loskutoff DJ, Samad F. The adipocyte and hemostatic balance in obesity: studies of PAI-1. Arterioscler Thromb Vasc Biol 1998;18(1):1-6.

29. Ragab A, Abousamra NK, Higazy A, Saleh O. Relationship between insulin resistance and some coagulation and fibrinolytic parameters in patients with metabolic syndrome. Lab Hematol 2008;14(1):1-6. doi: 10.1532/ LH96.07017.

30. Giordano P, Del Vecchio GC, Cecinati V, Delvecchio M, Altomare M, De Palma F, et al. Metabolic, inflammatory, endothelial and haemostatic markers in a group of Italian obese children and adolescents. Eur J Pediatr 2011;170(7):845-50. doi: 10.1007/s00431-010-1356-7.

31. Bęc L, Karolczak MA, Motylewicz B. The role of von Willebrand factor in endothelial damage in patients operated on with use of cardiopulmonary bypass - a review. Nowa Pediatr 2004;3:103-5.

32. Tsang GM, Allen S, Pagano D, Wong C, Graham TR, Bonser RS. Von Willebrand factor and urinary albumin excretion are possible indicators of endothelial dysfunction in cardiopulmonary bypass. Eur J Cardiothorac Surg 1998;13(4):385-91.

33. Chojnowski J, Ponikowska I, Szczawińska I, Jarkiewicz-Tretyn J. Evaluation of family history of obesity and diabetes mellitus in patients with severe obesity. Baln Pol 2006;2:91-4. 